\title{
ESTÁGIO CURRICULAR SUPERVISIONADO: UM ESTUDO DE CASO SOBRE AS PERCEPÇÕES DO PROFESSOR SUPERVISOR E SUA ESTAGIÁRIA
}

\author{
PRACTICAS CURRICULARES SUPERVISADAS: UN ESTUDIO DE CASO SOBRE \\ LAS PERCEPCIONES DE LA PROFESORA SUPERVISORA Y SU APRENDIZ
}

\author{
SUPERVISED CURRICULAR INTERNSHIP: A CASE STUDY ON THE \\ PERCEPTIONS OF THE SUPERVISING TEACHER AND HIS INTERN
}

\author{
Diane Mota LIMA ${ }^{1}$ \\ Miguel Ataíde Pinto da COSTA ${ }^{2}$ \\ José Henrique dos SANTOS ${ }^{3}$
}

RESUMO: O objetivo desta pesquisa foi comparar as percepções do Professor Supervisor (PS) e de sua Estagiária sobre todo o período de Estágio Curricular Supervisionado (ECS) na escola. A pesquisa se utilizou do método qualitativo, por um estudo de caso, na perspectiva de modelo analítico descritivo. Os participantes foram um Professor Supervisor de Educação Física da rede básica de ensino e uma estagiária de Educação Física, devidamente matriculada na atividade do ECS. Os instrumentos utilizados foram Notas de Campo, Entrevistas SemiEstruturadas e Documento do Relatório Final do estagiário, submetidos à técnica de Análise de Conteúdo. Os resultados dessa análise revelaram que a percepção de ambos sobre o mesmo período de estágio vivenciado foi bastante distinta. Esse estudo entende como necessário que os participantes dessa importante etapa da formação inicial trabalhem em parceria e conscientes dos papéis que representam e suas responsabilidades.

PALAVRAS-CHAVE: Formação de professores. Estágio curricular supervisionado. Educação física.

RESUMEN: El objetivo de esta investigación fue comparar las percepciones del profesor supervisor (PS) y de su aprendiz sobre todo el periodo de las prácticas curriculares supervisadas (SCS) en la escuela. La investigación utilizó el método cualitativo, mediante un estudio de casos, en la perspectiva del modelo analítico descriptivo. Los participantes fueron un profesor supervisor de educación física de la red de educación básica y un pasante de educación física, debidamente inscritos en la actividad de la ECS. Los instrumentos utilizados fueron las Notas de Campo, las Entrevistas Semiestructuradas y el Documento de Informe Final del aprendiz, sometidos a la técnica de Análisis de Contenido. Los resultados de este análisis revelaron que la percepción de ambos sobre el mismo periodo de prácticas

\footnotetext{
${ }^{1}$ Universidade Estadual Paulista (UNESP), Presidente Prudente - SP - Brasil. Mestrado pelo Programa de PósGraduação em Educação Física. ORCID: https://orcid.org/0000-0001-7933-2777. E-mail: dianemotalima@gmail.com

${ }^{2}$ Colégio Pedro II (CPII), Rio de Janeiro - RJ - Brasil. Professor da Rede Básica de Ensino do Colégio Pedro II. Doutorado em Epidemiologia em Saúde Pública (FIOCRUZ). ORCID: https://orcid.org/0000-0002-6498-3435. E-mail: miguelcosta.ef@gmail.com

${ }^{3}$ Universidade Federal Rural do Rio de Janeiro (UFRRJ), Seropédica - RJ - Brasil. Professor no Programa de Pós-Graduação em Educação e da Graduação em Educação Física. Doutorado em Ciências da Educação (ULISBOA) - Portugal. ORCID: https://orcid.org/0000-0002-2159-6611. E-mail: henriquejoe@hotmail.com
} 
experimentado era bastante diferente. Este estudio considera necesario que los participantes de esta importante etapa de la formación inicial trabajen en colaboración y sean conscientes de las funciones que representan y de sus responsabilidades.

PALABRAS CLAVE: Formación de profesores. Prácticas curriculares supervisadas. Educación física.

ABSTRACT: The objective of this research was to compare the perceptions of the Supervising Teacher (PS) and his Trainee about the whole period of the Supervised Curricular Internship (ECS) in the school. The research used the qualitative method, through a case study, in the perspective of a descriptive analytical model. The participants were a Physical Education Supervisor Teacher from the basic education network and a Physical Education intern, duly enrolled in the ECS activity. The instruments used were Field Notes, Semi-structured Interviews and a Final Report Document of the intern, submitted to the Content Analysis technique. The results of this analysis revealed that the perception of both participants about the same internship period was quite different. This study considers it necessary that the participants in this important stage of initial formation work in partnership and are aware of the roles they play and their responsibilities.

KEYWORDS: Teacher education. Supervised curricular internship. Physical education.

\section{Introdução}

No processo de formação inicial docente, o período do Estágio Curricular Supervisionado deve ser considerado como um "momento de exploração e aproximação da realidade, oportunidade de aprendizagem da profissão e de construção da identidade profissional" (PIMENTA; LIMA, 2019, p. 99-100).

O estágio supervisionado se constitui em importante período da formação inicial por oportunizar a reflexão sobre a dicotomia entre teoria e prática, ainda muito frequente nos cursos de formação de docentes.

Todos os participantes da escola devem colaborar e se sentir responsáveis pela formação do estagiário que recebe na unidade escolar, mas quem mais se destaca nessa importante função é o Professor Supervisor.

Para Sarti (2009), o professor supervisor (que recebe o estagiário em suas aulas) deve ser formado e habilitado com competências específicas para interagir com o estagiário no ambiente escolar. A função principal do professor é promover uma maior aproximação do estagiário a sua futura realidade laboral e permitir, com isso, a ampliação dos conhecimentos oriundos da ação pedagógica.

A legislação (BRASIL, 2001) é clara sobre a regulamentação do estágio nas universidades e nas escolas, esclarecendo diversas questões documentais e processuais, mas 
não pontua como esse professor supervisor receberá a adequada formação continuada das universidades ou secretarias de ensino para acolher, verdadeiramente, o estagiário em suas aulas. De acordo com Souza Neto e Benites (2013), a legislação do estágio não contempla a formação do professor que orienta estagiários em suas aulas.

A ideia de acolhimento amplia e vai além do conceito de receber o estagiário na escola, significando um trabalho preocupado com a formação de qualidade do estagiário. Desse modo, o acolhimento se define como uma forma especial de receber o estagiário na escola, que considera sua história, formação e o faz se sentir parte do dia a dia escolar.

Para que haja um desenvolvimento profícuo do estágio supervisionado é importante que os participantes desse processo tenham uma relação próxima, em parceria, ao longo de todo o processo de estágio na escola. O professor supervisor deve demonstrar interesse e querer fazer parte da formação inicial do seu estagiário, oportunizando diversas ações e possibilidades no ambiente escolar.

Com isso, essa pesquisa buscou identificar quais as percepções que o professor supervisor e seu estagiário tiveram do mesmo período de estágio vivenciado.

Essa pesquisa entendeu como importante analisar de forma comparativa como ambos se vêm dentro desse processo de estágio, pois a percepção e reflexão do próprio papel são importantes para a construção de um ECS verdadeiramente positivo.

\section{Caminhos Metodológicos}

Esse estudo teve como método o qualitativo, documental, do tipo estudo de casos, utilizando-se dos procedimentos do modelo analítico descritivo. Os instrumentos utilizados foram entrevistas do tipo semi-estruturada (inicial e final), observações in loco com notas de campo e o documento institucional Relatório Final de Estágio.

Nesta pesquisa, os participantes foram uma dupla formada pelo Professor Supervisor de Educação Física da rede básica de ensino e sua Estagiária, aluna do curso de Licenciatura em Educação Física da Instituição de Ensino Superior (IES) pesquisada, devidamente matriculada na atividade de estágio. Os nomes dos participantes, ficticiamente adotados, são: professor Alan e estagiária Alice.

O período total de coleta dos dados foi de dois meses, totalizando oito dias de observação in loco, em um total de 20 horas de observação.

Após a coleta, os dados foram tratados e analisados sob a técnica de Análise de Conteúdos (BARDIN, 1977). Essa técnica de análise objetiva interpretar a mensagem do 
conteúdo manifesto e do conteúdo latente do autor, sem interpretação subjetiva do pesquisador, ou seja, tudo aquilo que foi declarado e/ou ficou subentendido de forma simbólica.

Para aprofundar mais a análise dos dados, foram construídas nessa pesquisa as Categorias de Indicadores, que são ações e posturas adotadas pelo professor supervisor ao seu estagiário na escola durante o período do Estágio Curricular Supervisionado. São eles: Chegada, Apresentação de Instrumentos Pedagógicos (escola/professor), Disponibilidade de Comunicação e Demonstração de Interesse na Formação do Estagiário, Expectativas com o Estagiário, Participação do Estagiário, Socialização Profissional do Estagiário, Orientação e Feedback, Relacionamento entre PS e Estagiário e Reflexão sobre a Prática e Carreira Docente.

\section{Resultados e Discussões}

\section{Chegada do estagiário}

\section{Percepção do Estágio Supervisionado do Professor Supervisor Alan}

Sobre o momento de recepção dos estagiários, o professor supervisor Alan relatou que faz "basicamente uma entrevista, um papo mesmo sobre a vida", e com ela procura saber logo se o estagiário tem interesse na docência, pois alegou que se o estagiário o procura apenas para cumprir a carga horária da atividade, ele não vai dispor de mais tempo e dedicação nesses casos, transmitindo suas experiências docentes. E acrescentou que o estagiário que demonstra mais interesse pela educação tem mais de sua atenção e disponibilidade. "Mas o estagiário que chega lá já... olhando pra porta... é o básico, sabe? É uma relação prejudicial, acho que até pra ele, mas até pra ele do que pra mim porque depois ele vai embora, e eu continuo aqui" (Entrevista Inicial).

O professor Alan comentou que a estagiária Alice foi bem recebida na escola, tanto pela equipe de gestão quanto por ele, e que a rotina realizada com a estagiária Alice foi pautada no esforço e superação da estagiária.

\section{Percepção do Estágio Supervisionado da Estagiária Alice}

Sobre a sua recepção à escola, a estagiária Alice disse que foi muito bem recebida pela direção e funcionários da escola e que não teve qualquer problema na escolha dos horários e assinaturas de documentos do estágio. 
A recepção do professor supervisor Alan também foi colocada pela estagiária como positiva, porém destacou algumas perguntas que o professor fez a ela logo no primeiro dia de estágio: "Aí eu cheguei na escola, ele me... recebeu bem, perguntou como é que eu tava (estava), perguntou se eu ainda não tinha desistido da profissão (risos)... eu falei que não, que eu não ia, eu falei: 'não, nem vou!' (risos)... foi assim”. (Entrevista Inicial).

A estagiária Alice relatou que as atividades pedagógicas destinadas a ela eram da área de Educação Física e que não foi remanejada para outra função dentro do ambiente escolar: "Sim, foram da área de Educação Física. Acho que se me fosse oferecido até da área pedagógica para ficar só em sala, eu não ia aceitar porque eu quero estagiar na área que eu estou me formando" (Entrevista Inicial). Comentou também que ficou quase um mês observando as aulas, por vontade própria para conhecer melhor as turmas.

Sobre a apresentação do espaço físico, a estagiária relatou que o professor supervisor Alan caminhou com ela pelas áreas externas da escola, deixando outros setores sem o conhecimento da estagiária. "Eu conheço mais os espaços em que eu preciso utilizar que é a área externa, a quadra, algumas salas de aula, mas a sala dos professores, por exemplo, eu não conheço, e têm outros espaços que são desconhecidos para mim”" (Entrevista Inicial).

\section{Apresentação de Instrumentos Pedagógicos (escola/professor)}

\section{Percepção do Estágio Supervisionado do Professor Supervisor Alan}

Sobre o planejamento do estagiário, o professor Alan esclareceu que não pediu nada formal. "[...] ela me mostrava. Ela tentava ao máximo mostrar os tópicos do que ela iria fazer. Eu não exigi dela nenhum plano de aula, não, algo formal como num estágio, mas um mínimo de organização e ela atendeu ao que foi pedido" (Entrevista Final).

Acrescentou também que pretendia pedir que a estagiária deixasse o "plano de aula na manga" para que, a qualquer momento, ele possa direcioná-la para ministrar uma aula completa, ou seja, para que a estagiária ministrasse todos os passos da aula sem a intervenção do professor supervisor, aprendendo a lidar assim com as possíveis frustrações. "Se o estagiário pegou a turma e perdeu o controle da turma e não conseguiu, eu vou deixar que ele tenha essa experiência mesmo que ela seja ruim porque ele precisa aprender a lidar com a frustração" (Entrevista Inicial). 


\section{Percepção do Estágio Supervisionado da Estagiária Alice}

Sobre o planejamento e a identidade da escola, a estagiária Alice afirmou que não teve acesso a qualquer planejamento ou apresentação da identidade da escola. "Não me foi apresentado (planejamento)" (Entrevista Inicial).

A estagiária Alice reafirmou na Entrevista Final que não houve qualquer planejamento apresentado a ela durante o período de estágio: "Não havia (planejamento), não havia. Porque ele sempre disse para mim que criança tem que ficar solta para brincar" (Entrevista Final).

A estagiária comentou que o professor supervisor não pediu os planejamentos dessas aulas ministradas e que foram confeccionados por ela, com pouco suporte do professor supervisor. "Então, eu fui pensando, tudo na minha mente. Não, ele não quis. Ele não pediu (planejamento), só escrevi. Eu até levei para o dia da aula para dar uma ajuda" (Entrevista Final).

\section{Disponibilidade de Comunicação e Demonstração de Interesse do PS na Formação do Estagiário}

\section{Percepção do Estágio Supervisionado do Professor Supervisor Alan}

Quando perguntado sobre como concebia sua função junto ao estagiário nesse processo de formação que estava iniciando, o professor comentou ser um assunto complexo e não ter certeza se consegue exercer sempre sua função, mas que a entende como "a função de dar oportunidades e chance dele (estagiário) viver a experiência da docência”. Acrescentou ainda que gostaria de ser visto pelo estagiário como um parceiro, alguém que possa de fato ajudar e não apenas como um professor que assina a "folhinha dele, ou pra acuá-lo e colocálo na situação de menosprezo." (Entrevista Inicial).

O docente Alan pontuou a sua concepção sobre o próprio papel no processo de formação do futuro e se definiu como "conselheiro" da estagiária sobre as vivências pedagógicas.

O professor acrescentou ser grande a responsabilidade de ter outra pessoa compartilhando de suas aulas e da necessidade de "lembrar" de fornecer os feedbacks e informações para a estagiária.

A responsabilidade ela traz um peso, que não chega a ser desconfortável, não é isso. Mas o peso da responsabilidade que tem alguém que está ali que eu preciso me dedicar esse pouquinho a mais porque eu tenho alguém ali ao 
meu lado, eu não to sozinho e vou fazer sozinho. Tenho que lembrar de está sempre passando o feedback para ela para não ficar perdida no que eu vou fazer. Sem ela, eu não preciso dizer a ninguém o que eu vou fazer. Eu chego e faço. Eu tinha que ter esse cuidado de lembrar de estar sempre... Teve um dia que eu esqueci de avisar a ela que não tinha aula, ai ela chegou, essas coisas. de ter alguém (Entrevista Final).

\section{Percepção do Estágio Supervisionado da Estagiária Alice}

Para a estagiária, o professor não demonstrou interesse nas atividades de estágio: "Não, e ele não demonstrava interesse". A estagiária ainda acrescentou que o professor Alan não deveria ser professor supervisor de estagiários, pois não apresentou ter conhecimento sobre a orientação e acompanhamentos de estagiários, assim como, seu papel na formação deles. "Eu acho que ele não deveria atuar como professor de estágio. Ele não tem orientação suficiente pra ser supervisor de estágio, dá pra ver pelas atitudes dele. Ele deixa os estagiários muito soltos, por conta própria” (Entrevista Final).

Certo dia, a estagiária Alice concedeu uma Entrevista Extra à pesquisadora e relatou como ficou desapontada com o professor supervisor, por este ter se ausentado da escola sem avisá-la com a devida antecedência: "Eu fiquei mofando. Aí ele foi e eu fiquei esperando esse tempo todo... e... agora eu fico imaginando se eu tivesse chegado na escola... antes de encontrar... depois dele sair... eu ia ficar sem informação nenhuma... entendeu? Porque ele não me avisou” (Entrevista Extra). Tal situação foi relatada também na sua Entrevista Final e em seu Relatório Final de Estágio como o "lado negativo" desse estágio. De acordo com a estagiária Alice, em outra ocasião, ocorreu algo parecido novamente.

Sobre essas situações, a estagiária criticou a "falta de respeito" e "falta de comunicação". "Não teve aviso prévio, eu acho falta de comunicação, falta de respeito com o estagiário. É como se assim: 'você se vira do seu jeito e eu faço o meu lado'. Eu fico pensando: 'Imagina se eu morasse longe? Como é que ia ser para mim?" (Entrevista Final).

\section{Expectativas do PS com o Estagiário}

\section{Percepção do Estágio Supervisionado do Professor Supervisor Alan}

O professor ainda esclareceu que espera de um estagiário "o mínimo de dedicação... o mínimo porque às vezes nem isso, nem isso chega, entendeu?" e que tenha intenções de aprender a fazer, de aproveitar oportunidades e de conhecer as rotinas de uma escola. Além disso, o professor relatou que espera dedicação e envolvimento do estagiário com "aquele 
brilho no olho e que ele venha aberto a viver experiência. Eu espero mesmo a postura e o compromisso deles na orientação com as crianças" (Entrevista Inicial).

O professor Alan destacou que o estagiário deve apresentar uma "postura e atitude respeitável, assim tem grande chance de sucesso, de evitar conflitos e de ter uma relação boa com a escola e com os outros agentes da escola". O professor ainda pontuou que o estagiário que apresenta uma postura mais displicente tem grandes chances de se envolver em problemas, principalmente, "porque não vai ter o respeito das crianças" (Entrevista Inicial).

$\mathrm{O}$ professor Alan comentou que pretendia pedir à estagiária que fosse parceira e que tivesse postura de professora nos momentos de aula e complementou que para isso evita usar o termo estagiário perante a turma, apresentando o estagiário como professor ou professor formando, para que os alunos o enxerguem assim.

Sobre as questões de aula, o professor destacou que espera que a estagiária tenha aprendido a ser mais flexível e ter "jogo de cintura" com situações inesperadas e "sensibilidade" para perceber quando não é possível dar continuidade ao planejamento previamente estabelecido (Entrevista Final).

\section{Percepção do Estágio Supervisionado da Estagiária Alice}

A estagiária Alice comentou ter boas expectativas com o atual estágio, apesar de ter algumas posições críticas e que acredita que terá grandes ensinamentos sobre o cotidiano pedagógico de uma escola. "Por mais que eu tenha uma visão crítica de muitos pontos do meu estágio, acredito que eu vou sair daqui com uma visão bem madura do que é a realidade da escola" (Entrevista Inicial).

Mesmo no início do período de estágio, a estagiária Alice pontuou negativamente a contribuição do professor Alan na sua formação e suas primeiras impressões sobre as aulas: "Não está sendo muito agradável porque a forma dele ministrar as aulas são totalmente contrárias ao que é correto. Normalmente ele não passa atividades para as crianças, as crianças fazem atividades livres, algumas sobem em árvores e outras chutam bola aleatoriamente, não estou tendo uma boa experiência por causa disso” (Entrevista Inicial).

\section{Participação do estagiário no cotidiano escolar}

\section{Percepção do Estágio Supervisionado do Professor Supervisor Alan}

O professor Alan comentou que a estagiária teve oportunidade de realizar diversas funções inerentes às de professor, tais como a condução de aulas, buscar turmas em sala e 
material para as aulas. "Ela teve oportunidade de fazer um pouco de tudo. Desde conduzir turma, buscar em sala, às vezes eu pedia que ela buscasse a turma sozinha e para levar, conduzir um momento da aula, buscar material, para conhecer a rotina da escola" (Entrevista Final).

O professor Alan comentou que nos momentos de intervenção da estagiária nas aulas, ele preferiu não intervir e ficar distante, apenas em casos que fugissem ao controle da estagiária, e que os conteúdos dessas aulas eram selecionados por ele e a estagiária, "com total liberdade". Sobre o comportamento da turma. "Eu até me afastava, olhando o mais de longe possivel para turma não vir me procurar para pedir para beber água, 'ó, é com ela!' E eu ficava observando à distância" (Entrevista Final).

$\mathrm{O}$ professor comentou que a estagiária sempre demonstrou boa receptividade às intervenções dele e apresentou um comportamento inseguro nas aulas. "Eu só percebi insegurança quando chegou o momento da aula... a gente construiu uma relação de muito diálogo. E era tranquilo. Até quando ela não tava apta a fazer alguma coisa, ela falava”.

Nesses momentos de intervenção nas aulas, o professor supervisor relatou que a estagiária organizava atividades que nem sempre davam certo e que não tinha problemas em receber um conselho.

$\mathrm{Na}$ opinião do professor, as intervenções nas aulas da estagiária foram como ele esperava, e que até quando ocorria algo diferente do planejado pela estagiária, já tinha sido previsto por ele. "Olha, eu posso dizer que saiu como eu esperava porque até o que deu errado era previsto dar errado [...]. Então nada fugiu ao controle” (Entrevista Final).

\section{Percepção do Estágio Supervisionado da Estagiária Alice}

Sobre os seus momentos de intervenção, a estagiária Alice relatou que após o período de observação das aulas, começou a ministrar aulas para diversas turmas. Nesses momentos de intervenção, o professor supervisor não apresentou muito interesse e se afastava do local das aulas. "Então, ele me deixou sozinha com as crianças. Ele se afastou, lá ele não tinha como intervir, entendeu? Então, praticamente é como se eu tivesse ficado sozinha, na parte externa" (Entrevista Final).

Ainda sobre as intervenções, a estagiária relatou que ficou assustada quando o professor supervisor Alan pediu que assumisse a turma sozinha, ela acredita que o professor deveria ter sido outro, mais atencioso. "Eu fiquei um pouco assustada [...] maior insegurança, na verdade, porém, eu acho que o professor deveria estar lá é... se dispondo caso (eu) precisasse de alguma coisa” (Entrevista Final). 
A estagiária acrescentou que na sua terceira intervenção nas aulas contou com pouca orientação do professor supervisor para seu planejamento e que se organizou sem auxílio. " $A$ minha terceira aula eu ministrei sozinha, montei o meu plano de aula sem o auxílio do professor orientador do estágio, e pensei nos materiais que eu iria utilizar, que foram bola e cones" (Entrevista Final).

E continuou sobre a postura do professor supervisor nesse dia da sua intervenção: "No momento dessa atividade o professor ficou afastado, observando de longe e tomando conta de uma outra turma que ele juntou no dia e que separou da área onde eu aplicaria as atividades, pois eram turmas diferentes". (Relatório Final).

\section{Socialização Profissional do Estagiário}

\section{Percepção do Estágio Supervisionado do Professor Supervisor Alan}

Sobre a socialização profissional da estagiária no ambiente da escola, o professor comentou que foi "muito pouco" devido a ele sempre estar presente e resolver as questões. " $E$ não teve necessidade dela por em prática esses contatos muito assim, mas o pouco que precisou... 'precisava pegar aquela chave lá, tem como pedir ao funcionário tal?' Ela tranquilamente sabia quem era" (Entrevista Final).

Sobre a relação com os alunos, o professor descreveu que no início a estagiária teve muita insegurança e transpareceu estar assustada com aquela nova realidade, mas que aos poucos foi conseguindo lidar com as diversidades. "Ela tem um bom relacionamento com crianças. De repente ela já deve ter alguma experiência de recreação, não sei." (Entrevista Final).

Os espaços mais frequentados pelo estagiário, na fala do professor, foram a quadra e o jardim de trás da escola (pátio ao ar livre), e eventualmente iam ao parquinho e ao auditório, em dias de chuva.

\section{Percepção do Estágio Supervisionado da Estagiária Alice}

Em uma avaliação da estagiária sobre seu período de estágio nessa escola, relatou que aprendeu muito sobre o relacionamento com os alunos, porém, não atribuiu esse aprendizado ao professor supervisor, concluindo que aprendeu sozinha. "Não, isso (amadurecimento) foi uma coisa que eu criei na hora de tentar me virar sozinha, entendeu? Isso dai foi como se eu tivesse me auto-amadurecido sem aquele calorzinho (nervosismo), entendeu?" (Entrevista Final). 
De acordo com a estagiária, o relacionamento com a direção da escola e com os outros funcionários da escola foi pequeno, mas que sempre foi bem tratada por todos quando precisou entrar em contato: "Eu não tive uma ligação direta com os funcionários, mas às vezes que eu tive contato com eles pra buscar alguma informação, pegar algumas assinaturas, eu fui bem tratada".

Sobre o contato com outros professores da escola, a estagiária pontuou que foram raros e que a baixa comunicação do professor supervisor com os demais colegas pode ter influenciado a sua interação com eles. "Já os demais professores da escola, estes costumavam ser educados comigo quando eu trocava alguma palavra com eles que, não era sempre, pois o professor docente não mantinha essa ligação com os demais” (Relatório Final).

Ela acrescentou que quando tinha um intervalo entre as aulas, ficava na quadra aguardando a próxima turma e que nem sempre o professor supervisor ficava no local com ela: "A gente (estagiária e pesquisadora) ficava na quadra, logo na entrada da escola. Eu ficava lá... esperando o tempo passar, fazer o que tinha que fazer” (Entrevista Final).

\section{Orientação e Feedbacks}

\section{Percepção do Estágio Supervisionado do Professor Supervisor Alan}

Quando perguntado sobre a avaliação do período de estágio da Alice, o professor comentou que atuação foi "boa, muito boa. Regular em alguns momentos, mas por questão de insegurança, o que é perfeitamente compreensível. Não por desinteresse, jamais, ou por incapacidade". O professor acrescentou ainda ser normal esse comportamento, por ser o estágio o local de aprender o “conhecimento prático de aula” (Entrevista Final).

O professor supervisor acrescentou que não houve necessidade de qualquer correção por comportamentos inadequados da estagiária e que a orientou sobre questões pedagógicas. "Em termos de postura, de comportamento ético, nada. O que a gente pontua é questão pedagógica”. O professor ainda pontuou a necessidade da estagiária desenvolver a autoconfiança e que, na sua opinião, isso dependeria de alguns fatores. "Não sei qual é o interesse profissional dela na Educação Física [...], então, se ela quiser ser professora, ela vai precisar trabalhar um pouco a autoconfiança perante a turma" (Entrevista Final).

Ainda sobre a avaliação da estagiária, o professor comentou ter sido proativa e ter ficado muito à vontade para correção, elogios, ensinamentos e suporte aos alunos, em casos de necessidade. O professor Alan resumiu o aproveitamento da estagiária como: “Então, o aproveitamento dela, sem dúvida, foi de bom para excelente” (Entrevista Final). 


\section{Percepção do Estágio Supervisionado da Estagiária Alice}

Os momentos de feedbacks do professor supervisor à estagiária também foram poucos e, de acordo com a estagiária Alice, o professor parecia não ter conhecimento da sua importância no processo do estágio supervisionado. "O diálogo entre professor-aluno, a troca de informações, em muitos momentos faltou, tive muitos momentos de estresse, acho que ele não tinha noção da importância que é esse estágio supervisionado" (Entrevista Final).

A estagiária ainda acrescentou que não houve qualquer avaliação do professor supervisor sobre sua prática pedagógica, apenas tomou conhecimento de alguns pontos quando o professor preencheu os documentos de estágio. "Só na hora de entregar para ele a folha da autoavaliação. Saiu preenchendo e depois só me deu para eu assinar onde eu tinha que assinar, e aí eu vi que deu um feedback positivo pra mim” (Entrevista Final).

Quando perguntada se sofreu alguma correção nas aulas do professor supervisor, a estagiária relatou que não recebeu orientações de correção e que tiveram momentos que o professor se ausentou da quadra: "Na primeira atividade que eu apliquei em grupo, ele não quis, ele não ficou perto também... ele até saiu da quadra. Ele foi lá para a secretaria, no dia. E... no dia que eu apliquei a atividade ele também se afastou”" (Entrevista Final).

\section{Relacionamento entre Professor Supervisor e Estagiário}

\section{Percepção do Estágio Supervisionado do Professor Supervisor Alan}

O professor Alan acrescentou que teve um relacionamento "excelente" com a estagiária e que teve suas expectativas alcançadas com relação ao estágio da Alice. Porém, ele acrescentou sua insatisfação em não ter conhecimento prévio sobre o tempo que poderá contar com o estagiário em suas aulas. "O momento que ela esteve foi muito bom, mas o ideal é que a gente já soubesse previamente: 'Ó, começou o ano, o estagiário vai estar lá a partir de tal semana e vai ficar até a semana tal'. Até para saber se vai dar tempo de combinar com ela ou com ele" (Entrevista Final).

Ele ainda destacou que espera que a estagiária Alice o tenha enxergado como um amigo, como alguém que estava ali para ajudar e quando perguntado se teria algum último conselho ou sugestão para a estagiária Alice, o professor disse "pensa, observa o que foi vivido, o que foi visto e considera os pontos positivos e negativos para saber se valem a pena dentro do que ela deseja como profissional" (Entrevista Final). 


\title{
Percepção do Estágio Supervisionado da Estagiária Alice
}

Para a estagiária Alice é importante para o sucesso do estágio supervisionado que o professor supervisor participe sempre "ajudando de alguma forma no direcionamento das práticas do estagiário e divida conhecimentos", e sugere que professor Alan deveria "se portar melhor com os estagiários porque vão ser futuros professores, e que se ele acha que não teve uma boa formação, deveria dar esse tipo de formação digna pra quem estiver chegando à escola, o estagiário não tem que sofrer, está lá pra aprender”. (Entrevista Final).

Sobre o relacionamento com o professor supervisor Alan, a estagiária esclarece que foram momentos positivos com o professor, apesar de alguns momentos de estresse com ele durante as aulas do estágio. "Eu tive momentos agradáveis e bem chatos com o professor, alguns estresses por umas atitudes que ele tinha comigo. Ele fazia pouco caso de muita coisa. Mas no geral, eu tentava lidar bem com ele na medida do possível” (Entrevista Final).

Ainda sobre o relacionamento com o professor supervisor Alan, a estagiária Alice pontuou desapontamento com os poucos momentos de orientação ou demonstração de interesse pela sua formação. Na opinião da estagiária, o professor parece não ter formação adequada para orientar estagiários em suas aulas.

\begin{abstract}
Muitas vezes ele não demonstrava estar disposto a trocar conhecimentos comigo ou sugerir alguma atividade para realizar com os alunos, sempre era eu fazendo pergunta. É lamentável essas situações aqui expostas, pois sabe-se o quanto a relação do professor com o estagiário é primordial para que o andamento do estágio seja de forma agradável e proveitosa, e consequentemente enriquecedora para ambos. Apesar disso, eu sempre mantive o profissionalismo na frente e sempre o tratei com respeito, o vi como um colega de profissão pois estou ciente de que os professores do estágio supervisionado aceitam receber nós, os estagiários, porém os mesmos não possuem o embasamento suficiente para que possa servir de orientação, durante o andamento do estágio (Relatório Final).
\end{abstract}

\section{Reflexão sobre a prática docente no cotidiano escolar}

\section{Percepção do Estágio Supervisionado do Professor Supervisor Alan}

Sobre o aprendizado da estagiária Alice em um ambiente escolar real, o professor Alan esclareceu a importância da estagiária ter presenciado a necessidade da flexibilidade no cotidiano escolar. "Flexibilidade, acho que foi um ponto forte. A gente trabalha numa escola, como qualquer escola, que existem fatores externos ao nosso planejamento, interfere. Como nesse dia que teve que juntar uma turma, falta água, ta chovendo muito, só veio metade da 
turma (...)”. Destacou também que espera que a estagiária tenha aprendido sobre o funcionamento e a realidade da vida de professor. "Eu perguntava para ela: 'Vale a pena mesmo ser professor? Ou partir para uma outra área? Ganha tanto, faz isso, tem esse tipo de cobrança"," (Entrevista Final).

Sobre as questões de aula, o professor destacou que espera que a estagiária tenha aprendido a ser mais flexível e ter "jogo de cintura" com situações inesperadas e "sensibilidade" para perceber quando não é possível dar continuidade ao planejamento previamente estabelecido (Entrevista Final).

\section{Percepção do Estágio Supervisionado da Estagiária Alice}

Sobre os conteúdos apreendidos nesse processo do estágio supervisionado com o professor supervisor Alan, a estagiária Alice afirmou que aprendeu a lidar com situações estressantes e a ser mais profissional, mesmo naqueles momentos em que discordava de algo. "Saber lidar com momentos estressantes e ser profissional nesses momentos (risos) porque, às vezes, eu estava lá, com raiva e estressada e eu não demonstrava, eu agia normal como tinha que agir durante o estágio" (Entrevista Final).

\section{Discutindo os dados...}

O professor supervisor Alan concebe o período do estágio curricular supervisionado como uma importante etapa da formação docente e acredita que a estagiária deve conhecer todos os espaços escolares e vivenciar todas as problemáticas inerentes a uma escola pública da cidade. Ele disse entender seu papel na formação profissional do estagiário como de bastante responsabilidade e espera ter sido visto pela estagiária Alice como um amigo que estava lá para ajudar.

O professor supervisor percebeu que ofereceu um estágio dotado de muita autonomia e que oportunizou à Alice o máximo de acesso à realidade escolar, proporcionando vivência antecipada de uma escola de verdade. Para ele, os espaços para a estagiária protagonizar sua autonomia junto aos alunos ocorreram nos momentos oportunos em que ele se ausentou da quadra, para que ela pudesse vivenciar a realidade de uma aula de Educação Física em uma escola pública. Alan avaliou o processo de estágio de forma positiva e destacou que a estagiária foi proativa, precisando apenas trabalhar mais sua insegurança nas aulas com os alunos. 
Toda essa disponibilidade favorece o relacionamento mais próximo do PS com seu estagiário e amplia as oportunidades de orientação sobre as aulas, os alunos, a escola, a carreira docente, entre outros (BUENO; SOUZA, 2012).

Porém, a percepção do PS sobre o acolhimento oferecido a sua estagiária é bem distinta da percepção que a estagiária teve desse mesmo período. Nas suas entrevistas, Alice pontuou o desinteresse do PS pelo estágio, com ausências das aulas e poucos momentos destinados à orientação e feedbacks das intervenções realizadas. Além disso, comentou a falta de organização, de planejamento das aulas e do convite de Alan para participar de outros espaços e eventos escolares, limitando a vivência com outros professores/funcionários da escola.

Por fim, a estagiária Alice acredita que teve a oportunidade de aprender a lidar com situações estressantes e ainda ser profissional nesses momentos, sem demonstrar raiva ou insatisfação, pois em alguns momentos de desacordo com o PS, conseguiu conduzir o estágio sem brigas ou aborrecimentos. Ela entendeu que Alan não exerceu o seu papel de orientador e formador nesse processo, pois não demonstrava interesse e/ou conhecimento de como deveria conduzir o estágio curricular supervisionado.

A estagiária percebeu que o período de estágio vivido foi profícuo e enriquecedor por ter tido a oportunidade de exercer um pouco da docência, mesmo que sem a devida supervisão da PS, orientações e feedbacks sobre suas intervenções e reflexões sobre suas práticas pedagógicas. E pontuou que Alan não deveria estar exercendo a função de professor supervisor, dada a ausência de formação ou habilitação para receber um estagiário em suas aulas.

Segundo Araújo (2014), o PS deve enxergar seu estagiário como um parceiro profissional e o colocar nessa posição frente a outros professores, funcionários e os alunos, como um futuro colega de trabalho em formação. Posturas como essas permitem ao estagiário mais segurança e autonomia para interagir e intervir no ambiente profissional.

Trata-se de uma relação de companheirismo bastante específica, um acompanhamento formativo cujo foco está no futuro da existência do acompanhado que, neste caso, é o estagiário. Em tal relação, aquele que acompanha (a professora parceira) coloca à disposição do acompanhado condições necessárias para que ele possa descobrir suas possibilidades, organizando situações propícias para a formação ou aproveitando as situações favoráveis (SARTI, 2013, p. 94). 


\section{Considerações finais}

A formação profissional do estagiário é de responsabilidade de vários participantes atuantes nesse processo: cada um exerce uma função distinta e igualmente importante. A universidade e a escola são dois espaços de formação e devem trabalhar em parceria para o verdadeiro sucesso do estágio curricular supervisionado (SARTI, 2009).

$\mathrm{Na}$ escola, o professor supervisor assume o protagonismo de receber e orientar o estagiário no ambiente, assim como, apresentá-lo o cotidiano docente. Mas para que isso seja de fato realizado o professor deve conhecer o seu papel de formador e ter interesse em fazer parte dessa importante etapa do licenciando. É fundamental que o professor reflita sobre suas ações e posturas junto ao seu estagiário, para que possa oportunizar um momento de estágio de qualidade (BENITES, 2012).

Neste estudo, a percepção do PS e de sua estagiária sobre o mesmo período de estágio foi bastante distinta e dotada de elementos, que configuram o estágio, vistos de forma diferentes. Essas diferenças dificultam e limitam o pleno desenvolvimento dessa importante etapa da formação inicial do graduando, trazendo prejuízos na vivência antecipada do local de futuro trabalho do estagiário.

Dentre os motivos que levam a essa situação, a percebida nesse estudo foi que o PS não possuía uma formação específica para receber e orientar um estagiário e não recebeu formações ou diretrizes pela universidade de origem do estagiário, situações essas que abriram espaço para um "fazer artesanal" do professor, agindo com a estagiária de maneira intuitiva e insegura. Esse fator pode ter influenciado a conduta e as diferenças nas percepções sobre o estágio supervisionado do professor supervisor e de sua estagiária.

Com isso, é fundamental a maior reflexão sobre o período do ECS e da formação especial desses professores supervisores, para que suas escolhas e atitudes com seus estagiários tenham maior consciência e intenção, oportunizando uma melhor experiência sobre o cotidiano docente.

AGRADECIMENTOS: À CAPES, pois o presente trabalho foi realizado com apoio da Coordenação de Aperfeiçoamento de Pessoal de Nível Superior - Brasil (CAPES) - Código de Financiamento 001. 


\section{REFERÊNCIAS}

BARDIN, L. Análise de conteúdo. Lisboa: Edições 70, 1977.

BENITES, L. O professor-colaborador no estágio curricular supervisionado em

Educação Física: perfil, papel e potencialidades. 2012. 180 f. Tese (Doutorado) - Instituto de Biociências de Rio Claro, Universidade Estadual Paulista, Rio Claro, 2012.

BRASIL. Conselho Nacional de Educação. Parecer CNE/CP 28/2001, de 2 de outubro de 2001. Dá nova redação ao Parecer CNE/CP 21/2001, que estabelece a duração e a carga horária dos cursos de Formação de Professores da Educação Básica, em nível superior, curso de licenciatura, de graduação plena. Brasília, DF: CNE, 2001. Disponível em: http://portal.mec.gov.br/cne/arquivos/pdf/028.pdf. Acesso em: 10 out. 2020.

\section{MOTA, D. Licenciandos de Educação Física no contexto do Estágio Curricular} Supervisionado: um estudo sobre indicadores de acolhimento. 2020. 176 f. Dissertação (Mestrado em Educação Física) - Universidade Estadual Paulista, Presidente Prudente, 2020.

PIMENTA, S.; LIMA, M. Estágio e docência. Ed. São Paulo: Cortez: São Paulo, 2019.

SARTI, F. M. Parceria intergeracional e formação docente. Educação em Revista, Belo Horizonte, v. 25, n. 2, p. 133-152, 2009.

SOUZA NETO, BENITES. L. Os desafios da prática na formação inicial docente: experiência da Educação Física da UNESP de Rio Claro. Cadernos de Educação, p. 02-22, set./dez. 2013.

\section{Como referenciar este artigo}

LIMA, D. M.; COSTA, M. A. P.; SANTOS, J. H. Estágio curricular supervisionado: um estudo de caso sobre as percepções do professor supervisor e sua estagiária. Revista IberoAmericana de Estudos em Educação, Araraquara, v. 16, n. 3, p. 2030-2046, jul./set. 2021. e-ISSN: 1982-5587. DOI: https://doi.org/10.21723/riaee.v16i3.14705

Submetido em: 20/11/2020

Revisões requeridas em: 09/12/2020

Aprovado em: 10/01/2021

Publicado em: 01/07/2021 